\title{
The Jump from Morbidity to Mortality: Lethality Evolved
}

\author{
Cameron A. Carlson, DrPH \\ Capella University \\ Dr.cameron.a.carlson@gmail.com
}

\begin{abstract}
As the world evolves and grows in both technological advancements and in population density, epidemics and pandemics will become a larger and greater threat. Viruses, in most cases, can be considered the perfect predator. These organisms grow, infect, spread, and in many cases kill if not treated. These viruses themselves do not mutate on their own, but rather need a large population to infect, adapt, and then mutate to survive. These jumps from host to host will eventually produce a virus that can adapt to multiple environments and kill very quickly. In addition, the advancement of vaccination and treatment technology can provide protection but also can remove defenses from the human immune system. The question is, how does the world keep a virus from mutating and becoming highly lethal in a densely populated world?
\end{abstract}

Keywords: COVID-19; Pandemic; Global Security; Virus Mutation; Lethality

\section{El salto de la morbilidad a la mortalidad: la letalidad evolucionó}

\section{RESUMEN}

A medida que el mundo evoluciona y crece tanto en los avances tecnológicos como en la densidad de población, las epidemias y pandemias se convertirán en una amenaza cada vez mayor. Los virus, en la mayoría de los casos, pueden considerarse el depredador perfecto. Estos organismos crecen, infectan, se propagan y, en muchos casos, matan si no se tratan. Estos virus en sí mismos no mutan por sí mismos, sino que necesitan una gran población para infectar, adaptarse y luego mutar para sobrevivir. Estos saltos de un host a otro eventualmente producirán un virus que puede adaptarse a múltiples 
entornos y matar muy rápidamente. Además, el avance de la tecnología de vacunación y tratamiento puede brindar protección, pero también puede eliminar las defensas del sistema inmunológico humano. La pregunta es, ¿cómo evita el mundo que un virus mute y se vuelva altamente letal en un mundo densamente poblado?

Palabras clave: COVID-19; Pandemia; Seguridad global; Mutación viral; Letalidad

\title{
从致病到致死的跳跃：致死性的演进
}

\begin{abstract}
摘要
世界在科技进步和人口密度方面不断演进和发展的同时, 流 行病和大流行将成为更大更艰巨的挑战。大多数情况下，病 毒能被视为完美的杀手。这些微生物繁殖、传染、扩散, 并 在许多情况下将夺走生命, 如果不经治疗的话。这些病毒不 会自身发生变异, 而是需要大量人群来传染、适应、接着产 生变异并存活。这些从一个宿主转移到另一个宿主的跳跃将 最终产生一种能适应多个环境并迅速致死的病毒。此外, 疫 苗和治疗技术所取得的进步能提供保护, 但也能削弱人体免 疫系统的防御。问题则是, 世界如何防止病毒变异、阻止其 在人口密集的世界里具有高致死性?
\end{abstract}

关键词：新冠肺炎（COVID-19）, 大流行, 全球安全, 病毒 变异, 致死性

\section{Introduction}

I

$\mathrm{n}$ the beginning of May 2019, little was known about the SARS-CoV-2 (COVID-19) virus except that it was a Novel Coronavirus. The 'Novel' means 'new' and the 'Corona or coronam' in Latin, refers to what the crown type spikes the virus appears to have under a microscope (Secon, 2020). Other Coronaviruses include SARS-CoV-1 (SARS of 2003 fame) and Middle East Respiratory Syndrome (MERS that made its rounds in 2012). The morbidity and transmission of COVID-19 virus was and is quite remarkable when compared to similar Coronaviruses. COVID-19, like its predecessors, SARS-CoV-1 and 
then MERS, made the zoonotic jump from animal to human with relative ease. However, COVID-19, very much like the Spanish Flu, spreads quickly. During the periods of SARS-1 and MERS, the stem of transmission was stopped through government intervention and strict measures. Unfortunately, the early symptoms COVID-19 displays resembled that of typical Pneumonia, and when cases were handled without the additional precautions in place today, was able to spread, and mutate, quickly.

Like other RNA viruses (Ebola, Influenza, Pneumonia, etc.) (Duffy 2018), COVID-19 has a vast genomic base and can mutate extremely quickly, creating a public health crisis attempting to contain it. COVID-19 has already mutated into more virulent and contagious forms (Duffy 2018) and will continue to do so, with the ability to potentially develop more lethal consequences.

\section{Coronaviruses Explained}

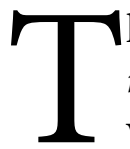

he family of Coronavirus (Coronaviridae) are not new types of viruses to the human species. These viruses can be classified into four types of subfamilies of CoV: (Alphacoronavirus (alphaCoV), Betacoronavirus (betaCoV), Deltacoronavirus (deltaCoV), and Gammacoronavirus (gammaCoV) (Cascella et al., 2021). The alpha and beta CoVs are seen more often in bats and rodent genomes. However, the delta and gamma CoVs are more often seen in avian species (Cascella et al., 2021).
The Beta CoVs, which includes COVID-19, have caused 2 other epidemics, not counting the current one, by making a zoonotic jump from animal to human. The Beta-CoV subfamily cause symptoms ranging from the common cold to the severe respiratory infections the world is currently experiencing.

Coronaviruses are positivestranded RNA viruses that normally reside in animals and have a vast genetic foundation consisting of 30,000 bases. Initially, the virus was spread from an animal host to a human at a wet (fresh or live meat) market in the Wuhan province in China (Cascella et al., 2021) sometime around October 2018. The initial zoonotic jump was a unique occurrence enabled by natural mutations in the original animal host. Current transmissions of COVID-19 have only been observed through human-to-human contact. As with other RNA viruses, such as the common cold or Influenza, the most common transmission is through aerosolization of fluids via coughing or sneezing (Cascella et al., 2021). Close contact with infected fluids is required for these viruses to effectively spread and continue their cycle of propagation. As with many Coronaviruses such as MERS and SARS-1, the cycle of infection can last up to 14 days.

One of the primary difficulties with COVID-19 is the potential for asymptomatic persons (individuals who show no symptoms) to contract the virus and spread it to close contacts. With a 14-day infection cycle the virus can spread to a significant number of individuals rapidly. This asymptomatic 
non-presentation makes contact tracing and identifying the original carrier extremely difficult. Finally, many of the Coronaviruses identified in creating epidemics and pandemics have large infection rates or R0 (pronounced R-naught) that determine how many people one person can/will infect. For example, COVID-19 has an R0 of 2.2; one person will infect 2.2 others. SARS-1, MERS, and SARS-2 all had/have R0s of 2.2 to 3.

\section{COVID-19's Historical Infection and Mortality Rates}

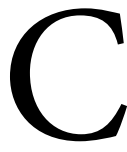

OVID-19 first appeared in Wuhan province in an individual who had visited the Huanan Seafood Market in October 2019 (Mizumoto et al., 2020). This individual later presented to the hospital with typical Pneumonia-like symptoms as was treated as such, survived and recovered. However, unbeknownst to the host and those who treated him/her, the illness was not Pneumonia; it was COVID-19, which had successfully transmitted to others who then carried on the cycle of transmission. It was not until 7 January 2019 that scientists narrowed the possibilities and temporarily label the new strain as 2019-nCoV (Allam et al., 2020). As the virus spread, the World Health Organization (WHO) declared the public health emergency a pandemic on March 11, 2020 (Mizumoto et al., 2020 ). With a R0 of 2.2 , or one person can infect 2.2 people, the virus was able to tally an exponential rise in case rates throughout the world. As with many novel viruses, high transmission rates almost always proceed high mortality (death) rates. In the case of COVID-19, this seemed to be true in the beginning. As not a great deal was known about this virus in the beginning, the mortality rates were reported to be as high as 6 to 7 percent (Loannidis 2020). That number has since dropped to approximately 0.27 percent (Loannidis 2020). This drop in mortality rate indicates that the higher the daily case rate or overall cases in the world, the mortality rate, unless exponential amount of people died, would lower. This drop, while a good sign, could point to a virus that is mutating to become a more lethal and/or virulent strain.

\section{The RNA Type Virus}

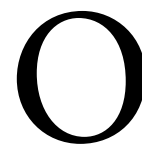
ne of the most concerning factors about COVID-19 that researchers should monitor more closely is its single stranded RNA (Ribonucleic Acid) structure. RNA differs from DNA in two distinct ways: 1) DNA contains Adenine, Thymine, Cytosine, Guanine. RNA contains the same except for Thymine. RNA contains Uracil. 2) RNA is single stranded and DNA is double stranded, which is why RNA can leave the nucleus of a cell and DNA cannot (Duffy 2018). This type of virus may exploit the presence of RNA-dependent RNA polymerases for replication of their genomes and mutate very quickly. Since COVID-19 has a long genome sequences (upwards of 30,000 genetic bases) it can mutate numerous times with hosts it infects (Duffy 2018). Normally, this is not of concern since a mutation most often causes a mistake in the genetic code and the new virus mu- 
tation will not survive. However, when a virus does mutate properly, it can create a new strain or variant of virus that can be more virulent or lethal. These mutations or new variants cause obstacles to the progress of stopping a pandemic because any vaccine that is produced is made to target one type of protein that the virus presents. When the virus successfully mutates to something different, vaccines that were once effective may become less effective or not effective at all (Gounder 2021). This is exactly why the Influenza vaccine must be given every year at the start of the season and still may not have a $100 \%$ success rate. To date, COVID-19 has successfully mutated multiple times into several different strains. The three that are currently distinguishing themselves and of major concern are the UK, South African, and South American variants.

\section{The Evolution of COVID-19}

$\mathrm{J}$ ust like any living creature, all viruses evolve or attempt to evolve, if they did not their species would eventually become extinct. While COVID-19 is able to mutate and therefore evolve very quickly due to the environment it has come to inhabit, the virus mutates only slightly and just drifts genetically (the gradual accumulation in any DNA sequence of random mutational changes that do not interfere with DNA's function), much like Influenza $\mathrm{A}$ and B. However, even with this genetic drifting, an individual's body can still recognize, respond, and fight to the best of its ability. If a virus is able to shift completely (the segmentation of the viral genome that supports the genetic re-assortment into one that the immune system does not recognize) (Nguyen 2020), the immune system's own response will further the infection due to the increased cellular load in the body and become the greatest threat to the host. These dramatic shifts have occurred with three different viruses in recent history causing very deadly pandemics: 1) 1918 Spanish Flu pandemic; 2) $1957 \mathrm{H} 2 \mathrm{~N} 2$ pandemic; and 3) 1968 H3N2 pandemic (Nguyen 2020).

The evolution of COVID-19 has been occurring since its introduction into the human population. However, what has made it prolific, is the ability and rate at which it has infected the human population. When a virus infects a person that virus is carrying all the information from the last infection, a library of information and mistakes. When it infects again or jumps to the next human host, it remembers its mistakes and changes. The virus becomes a very efficient organism and has the potential to become more efficient and lethal.

\section{The Immune Response to COVID-19}

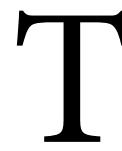
The human immune system is an indiscriminate killer, targeting and eradicating anything it sees as a threat. However, if the body begins to fight a virus with everything it has, the immune system is constantly taxed and flooding the body with cytokines, cellular detritus, interferon, and other products that produce toxic effects not only to a virus but also to the body itself. 
This production cells allows a virus to further infect an individual that could lead to feeling healthy one moment and dead within hours. If COVID-19 were to shift, the new forms of an antigen would be considerably different from the old antigen and no longer would bind to the antibodies, allowing the mutant virus to infect people who were immune to the original strain of the virus because of prior infection or vaccination (Nguyen 2020).

\section{Viral Loading}

$\mathrm{A}$ key term that has been used is "viral load" or "viral loading." The viral load in an infected person is the amount of the virus or the amount of the RNA material that is in the bloodstream at any given time. The amount of the virus in the bloodstream depends on the original dose an infected person has. However, this viral loading determines how the body and the immune system responds. Unlike a specific acquired immune response, where the body responds to a specific threat that it has seen before, the body reacts with a general response. When this occurs, the body produces cytokines and interferon which is toxic to both the body and the virus (Skinner 2020). The amount of the virus in the body determines how much and how hard the body will attempt to fight it. This is what leads to most of the deaths to elderly and young adults.

COVID-19 deaths are centered around a certain demographic. In this case, the demographic is the elderly population. The reason for this is mostly due to their already weakened immune system and/or pre-existing complications or comorbidity factors, or the existence of other factors which contribute to the death of an individual (Skinner 2020). However, as COVID-19 death pertains to mostly healthy young adults, this comes from several factors-one of them being when the immune system recognizes the virus and the current viral load. If a healthy adult contracts the virus and the initial infection is a large dose, the virus has more time to replicate and in large numbers. This will force an immune response that will produce large amounts of toxins to fight an infection. These toxins are in the form of Cytokines and Interferon that is deadly to a virus as well as to the human body. The large productions of these Cytokines occur, this is called a Cytokine Storm. A Cytokine Storm produces massive inflammation of the surrounding tissues and can cause those surrounding tissues to die and cause damage to the individual on a long-term basis or death.

Finally, one of the jobs of the immune system is to stand down the response once the virus or infection has been dealt with. This allows the body to clear itself of the toxins which that have been built up over the course of the attack. However, if the virus continues to replicate and the body cannot stop it, the body continues to flood with toxins and healthy tissues begin dying, such as Lung tissue in the case of COVID-19 and the individual enters ARDS (Acute Respiratory Distress Syndrome) or the entrance of fluid into the lung tissue (National Heart, Lung, and Blood In- 
stitute, 2019). COVID-19 overall effects the elderly population demographic, but can have vast effects on anyone who contracts a high enough initial dose or has other undocumented, pre-existing complications.

\section{Ways Ahead and \\ Recommendations}

$\mathrm{P}$ resently, COVID-19 has mutated to multiple more virulent forms such as the South African strain (501Y.V2), the United Kingdom strain (VOC202012/01), and the South American strain (501Y.V3) (Reardon 2021). These more virulent forms have enabled COVID-19 to transmit and infect at much higher rates than previously seen. When these strains mutate again, they may become even more virulent, and more lethal creating a perfect pandemic that could surpass the Spanish Flu in both morbidity (infection rates) and mortality (death rate).

Luckily, there are ways to stop a pandemic and slow a viruses' transmission and therefore mutation rates. These methods may seem simple in nature, but require strict adherence by every person and without compromise. They are:
1) Wear a mask when in close proximity with others
2) Maintain social distancing
3) Increase hand hygiene
4) Stay home if possible

5) Avoid large gatherings

6) Vaccinate

In 1918, the world came to terms with a pandemic that killed approximately 6 percent of the European population. The death toll was as high as 100 million people over 18 months, sadly a vaccine never came. Over 18 months the vaccination efforts of multiple countries raged, but technology of the time was un-successful in combating the pandemic. Had technology been able to develop a vaccine, such as the ones we have today, the death toll may have been markedly lower. Presently, the vaccination effort is ongoing and has made tremendous strides in such a short time period. Four companies have been able to produce highly effective vaccines against COVID-19 in relatively short timeframes.

Unfortunately, many people in this world feel that vaccines are not safe or are part of a larger conspiracy theory. These fears are widely unfounded and based on isolated incidents, anecdotal conjecture or are products of intentional disinformation campaigns. Without the efforts of scientists and medical professionals, COVID-19 would have more of a chance to become lethal and the world would be a much different place. Three things are needed to stop a pandemic: public health control methods, personal responsibility, and vaccinations are required. 
Cameron Carlson holds a DrPH in Public Health with a specialization in Epidemiology and an MA in Homeland Defense and Security. His primary area of research includes the application of statistics and trends for the prediction and tracking of viral agents through different population and socioeconomic demographics. Highlights from his research include the prediction and response of a new pandemic and the collaboration and response from both the private and public sectors. He welcomes opportunities for continued research and collaboration.

\section{References}

Allam, M., Cai, S., Ganesh, S., Venkatesan, M., Doodhwala, S., Song, Z., Hu, T., et al. (2020). COVID-19 Diagnostics, Tools, and Prevention. Diagnostics, 10(6), 409. MDPI AG. Retrieved from http://dx.doi.org/10.3390/diagnostics10060409.

Cascella M, Rajnik M, Aleem A, Dulebohn SC, Di Napoli R. Features, Evaluation, and Treatment of Coronavirus (COVID-19). 2021 Apr 20. In: StatPearls [Internet]. Treasure Island (FL): StatPearls Publishing; 2021 Jan-. PMID: 32150360.

Duffy, S. 2018. "Why are RNA virus mutation rates so damn high?" PLOS Biology 16 (8). https://doi.org/10.1371/journal.pbio.3000003. https://www.ncbi.nlm.nih. gov/pmc/articles/PMC6107253/.

Gounder, C, "Epidemic," 25FEB2021, 2021, in A more contagious and virulent varient (UK edition).

Loannidis, J. 2020. "The infection fatality rate of COVID-19 inferred from seroprevalence data." Bulletin of the World Health Organization. https://doi.org/10.2471/BL T.20.265892. https://www.medrxiv.org/content/10.1101/2020.05.13.20101253v3.

Mizumoto, K; Kagaya, K; Chowell, G. 2020. "Effect of a wet market on Coronavirus disease (COVID-19) transmission dynamics in China." International Journal of Infectious Diseases 97: 96-101. https://doi.org/https://doi.org/10.1016/j.ijid.2020. 05.091. https://www.sciencedirect.com/science/article/pii/S1201971220303982.

National Heart, Lung, and Blood Institute. 2019. "Acute Respiratory Distress Syndrome." Last Modified 17SEP2019. https://www.nhlbi.nih.gov/health-topics/ acute-respiratory-distress-syndrome.

Nguyen, H, H. 2020. "What is the role of antigenic shift in the pathogenesis of influenza?" Medscape. https://www.medscape.com/answers/219557-3453/what-is-therole-of-antigenic-shift-in-the-pathogenesis-of-influenza. 
Reardon, S. 2021. "The most worrying mutations in five emerging Coronavirus variants." Scientific American. Retrieved from https://www.scientificamerican.com /article/the-most-worrying-mutations-in-five-emerging-coronavirus-variants/

Secon, H. 2020. "The coronavirus' crown-like spikes give the virus family its name - here's what it looks like." Jan 28, 2020 Business Insider. Retrieved from https:// www.businessinsider.com/where-coronavirus-name-comes-from-2020-1

Skinner, M. 2020. Expert reaction to question about COVID-19 and viral load. In Roundups for journalists: Science Media Center. Retrieved from https://www. sciencemediacentre.org/expert-reaction-to-questions-about-covid-19-and-viralload/ 